\section{Crisis global, modelos de desarrollo y Bicentenario. Interrogantes sobre el «bien común»}

Daniel García Delgado
Daniel García Delgado es director del Programa Estado y Políticas Públicas, FLACSO - Sede Argentina. e-mail: dgarciad@flacso.org.ar
El autor agradece a todos los miembros e investigadores del Programa Estado y Políticas Públicas, FLACSO, por acompañar en el debate de las ideas aquí planteadas.

\section{Resumen}

La crisis global es importante tanto por su profundidad y significación económica y política, como porque impacta negativamente sobre el modelo de desarrollo en Argentina y en el conjunto de los países de la región. A partir de mediados del 2008, el mundo entró en otra era. La crisis financiera inicialmente generada en EEUU, finalmente se transfirió a la economía real de todo el mundo y terminó generando recesión y un cuestionamiento generalizado del paradigma predominante hasta entonces, el de la ortodoxia y la eficiencia de los mercados. Y si bien hay señales de que el proceso recesivo ha llegado a un piso, la situación es aún fluida, con problemas no resueltos y plagada de incertidumbres. De allí que nos propongamos, en primer lugar, contar con elementos para un debate estratégico en las actuales circunstancias, realizar un diagnóstico de la crisis global y sus tendencias más significativas. Analizar su impacto sobre el modelo de desarrollo en gestación en la Argentina, desde la salida de la crisis de inicios de la década (2001/2002) y distinguir cuáles son los interrogantes centrales que se presentan para el «bien común» en la actualidad. Por último, revisar los sentidos posibles del Bicentenario y su vínculo con un rumbo deseable a tomar desde una perspectiva ética del desarrollo.

\section{Summary}

The global crisis is important so much for its depth, economic and political significance, but also because it negatively impacts the development model in Argentina and the set of the countries of the region. From middle of 2008, the world entered into a new age. The financial crisis, initially generated in USA, finally transferred itself to the real economy of the whole world; and it finished generating recession and a widespread questioning of the predominant paradigm till then, that of the orthodoxy and the efficiency of the markets. And though there are signs from which the recessive process has come to a floor, the situation is still fluid, with problems not resolved and full of uncertainties. So in the first place, our propose is to count on elements for a strategic debate in the current circumstances, to realize a diagnosis of the global crisis and its more significant trends. Secondly, we will analyze its impact on the model of development emerging in Argentina, from the exit of the crisis of beginnings of the decade (2001/2002); at the same time, we will distinguish which are the central questions for the common good at the present. Finally, we will explore the possible senses of the Bicentennial and its link with a desirable course to take from an ethical perspective of the development. 